\title{
The effect of feeding frequency on the growth and composition of individual organs in the rat
}

\author{
By R. C. POCKNEE AND F. W, HEATON \\ Department of Biological Sciences, University of Lancaster, Lancaster $L A{ }_{4} Y Q$
}

(Received 9 April ${ }_{1975}$ - Accepted 4 fuly 1975)

\begin{abstract}
I. The effect of consuming the same total amount of food in either one large meal or several small meals per $\mathrm{d}$ was studied using weanling male rats.

2. The increase in total body-weight was the same in both instances, but the weights of the liver, kidneys, femur, small intestine and stomach were greater, and those of the spleen and residual carcass were smaller, in meal-eating rats than in continuously fed control animals. These differences persisted into the adult state.

3. No differences in gross chemical composition were found between the corresponding organs of the two groups of rats, and the differences in weight appeared to be the result of changes in the general growth rate of individual organs.

4. The hypertrophy of the kidneys in meal-eaters was due to an increase in mean cell size, but the increased weight of the liver and reduced weight of the spleen appeared to be largely the result of changes in the number of cells present.
\end{abstract}

Many nutritional studies involve the pair-feeding of animals on a daily basis, but although this practice equates the total food intake of animals in various groups, when a deficiency of an essential nutrient is involved it often leads to the development of different feeding patterns. Rats given deficient diets eat in a normal way at frequent intervals throughout the $24 \mathrm{~h}$, even after anorexia develops, but when the food restriction of controls becomes severe they adopt a meal-eating pattern of feeding, consuming their ration of food within a short time after it is provided and then fasting for the remainder of the day.

A meal-eating pattern of feeding modifies the metabolism of carbohydrates, lipids and proteins (Fábry, 1967), and increases in the activity of several enzymes involved in lipogenesis or glycogenesis have been found (Leveille \& Hanson, I966; Leveille, 1972). Previous studies in this laborator $y$ indicated that meal-eating affects the activity of alkaline phosphatase ( $E C$ 3.I.3.1 ) in various rat tissues (Heaton \& Loveless, 1973) and suggested that it may influence the growth of certain organs; therefore, the present study was undertaken to determine the effect of feeding frequency on the development of individual organs in young rats.

\section{EXPERIMENTAL}

\section{Animals and diets}

Three experiments were done in which weanling male Wistar albino rats weighing about $50 \mathrm{~g}$ were randomly allocated to the required number of groups and housed with two or three animals per cage. At 09.00 hours each morning meal-eating rats were given a weighed amount of food adjusted to what they could consume completely within the following $2 \mathrm{~h}$. Control rats received an equal amount of food per $\mathrm{d}$, but 
were fed automatically (Loveless, Williams \& Heaton, I972) so that food was provided almost continuously and they were able to eat with a normal frequency throughout the $24 \mathrm{~h}$ (Le Magnen, 1967). The amount of food was increased progressively as the size and appetite of the meal-eaters increased. Distilled water was provided ad lib. and the animals were weighed twice weekly.

The synthetic diet used in Expts $I$ and 3 was prepared by mixing the following ingredients $(\mathrm{g} / \mathrm{kg})$ : casein 200 , sucrose 660 , arachis oil 80 , cod-liver oil 20 , salt mixture containing major minerals and trace elements 40 , and purified vitamins. It was identical in composition with the complete diet used in association with mineraldeficiency studies in this laboratory (Alfaro \& Heaton, 1973). For Expt 2 commercial animal cubes (Oxoid 4I B; Oxoid Ltd, 20 Southwark Bridge Road, London SEI 9HF) were ground to a powder.

Expt I. Groups of twelve meal-eating and control rats received the synthetic diet for $24 \mathrm{~d}$, during which period the initial food intake of $4 \mathrm{~g}$ increased to $9 \mathrm{~g} / \mathrm{rat}$ per $\mathrm{d}$.

Expt 2. Three groups, each with twelve rats, received identical amounts of powdered cubes for $42 \mathrm{~d}$; the food consumption increased from 6 to $15 \mathrm{~g} / \mathrm{rat}$ per $\mathrm{d}$. The mealeating and control rats were fed as described previously, but animals in the 3 rd group received their daily ration of food in three equal meals at $09.00,17.00$ and oI.0o hours; this was achieved by using the appropriate compartments in the automatic feeding apparatus.

Expt 3. In a long-term study, groups of thirty meal-eating and control rats ate the synthetic diet for up to $75 \mathrm{~d}$. Six weanling rats were killed at the beginning of the experiment and batches of six animals from each group were killed at intervals during the experimental period; the rats were taken from different cages within the group.

On the final day all rats received half their normal amount of food and were fasted overnight before they were killed by prolonged diethyl ether anaesthesia. The bodyweight was determined and the liver, stomach, small intestine, large intestine, spleen, left femur and tibia, both testes, kidneys and submaxillary glands were removed and weighed; the lumen of the gut was first flushed with water to remove any contents. A sample of skin was obtained by cutting a circle of pelt from the dorsal pelvic region with a sharp cork borer; this gave a uniform sample with an area of $1075 \mathrm{~mm}^{2}$ which contained hair, skin and adhering subcutaneous tissue but had no obvious fat. The gastrocnemius and soleus muscles were removed together as a sample of skeletal muscle and the residual carcass was then weighed. The organs required for analysis were stored individually in plastic containers at $-20^{\circ}$.

\section{Analytical methods}

Individual organs were dried to constant weight at $105^{\circ}$. Soft tissues were then ground to a fine powder and portions of this were used for analysis. Nitrogen content was determined by the micro-Kjeldahl method, lipid content was determined by extraction with diethyl ether using a micro-Soxhlet apparatus and DNA content was determined after extraction with a hot solution of trichloroacetic acid $(5 \circ \mathrm{g} / \mathrm{l})$ (Hofert \& White, 1968) by colorimetric estimation using indole (Hubbard, Matthew \& Dubowik, 1970). The mineral content of whole bones and tissue powders was esti- 


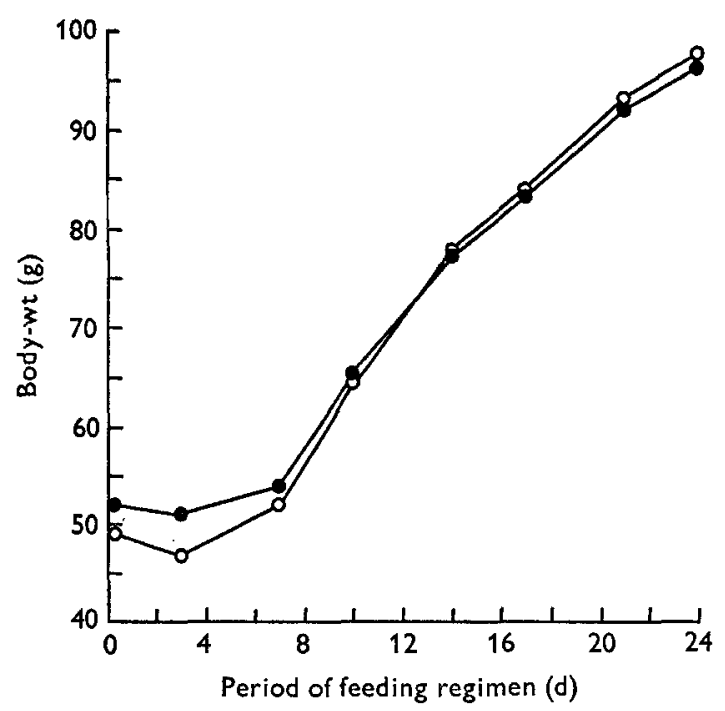

Fig. I. Expt I. Growth curves for meal-eating (๑) and continuously fed (O) weanling male rats consuming equal daily amounts of food for $24 \mathrm{~d}$. Mean values for twelve rats/group. For details of diets and feeding regimens, see pp. $97^{-8}$.

mated by dry ashing in a muffle furnace at $500^{\circ}$ for $48 \mathrm{~h}$. The statistical significance of differences was assessed by Student's $t$ test.

\section{RESULTS}

\section{Influence of feeding pattern on organ growth}

The body-weight of all rats remained almost constant until the meal-eaters became accustomed to taking the daily food within $2 \mathrm{~h}$ and their appetite increased, but from about the 7 th day onwards they grew steadily (Fig. I). The rate of growth was very similar in both meal-eating and continuously fed, control rats, and there was no significant difference between the gain in total body-weight of animals in the two groups in any experiment, indicating a similar efficiency of food utilization.

However, considerable differences between the weights of certain organs were found for the two groups of rats. This was studied most extensively in Expt $\mathrm{I}$ and the results given in Table $\mathrm{r}$ are expressed as the weights of individual organs relative to the total body-weight of the same rat to allow for variations in size between animals. The weights of the liver, kidneys, femur, small intestine and stomach were significantly greater in meal-eating rats than in control animals by amounts ranging from I I to $23 \%$ The spleen was the only organ found to have a strong tendency to be reduced in size in meal-eaters, but the lower weight of the residual carcass indicated that other tissues must also have grown more slowly in the meal-eaters than in control animals.

These differences were confirmed in Expt 2. The reduction in the weight of the spleen of meal-eaters was statistically significant due to lower variability among control rats, but the weight of submaxillary glands of meal-eating rats was increased by $17 \%$ 
Table I. Expt I. Weight of individual organs relative to total body-zveight of meal-eating and continuously fed (control) weanling male rats after $24 d$ on the respective feeding regimens*

(Mean values with their standard errors for twelve rats/group)

\begin{tabular}{|c|c|c|c|c|c|}
\hline \multirow{3}{*}{$\begin{array}{l}\text { Feeding regimen } \\
\text { Organ }\end{array}$} & \multicolumn{4}{|c|}{ Wt (g/kg body-wt) } & \multirow{3}{*}{$\begin{array}{c}\text { Statistical } \\
\text { significance of } \\
\text { difference between } \\
\text { mean values: } P\end{array}$} \\
\hline & \multicolumn{2}{|c|}{ Control } & \multicolumn{2}{|c|}{ Meal-eating } & \\
\hline & Mean & SE & Mean & $\mathrm{SE}$ & \\
\hline Liver & $44 \cdot 84$ & 0.71 & $49 \cdot 23$ & $I \cdot 29$ & $<0.01$ \\
\hline Small intestine & 36.09 & I.57 & 43.73 & $x \cdot 36$ & $<0.01$ \\
\hline Large intestine & 10.07 & 0.28 & $9 \cdot 52$ & 0.34 & $>0.2$ \\
\hline Testes & 16.63 & 0.62 & $18 \cdot 20$ & 1.03 & $>0.2$ \\
\hline Kidneys & 9.64 & 0.20 & $10 \cdot 58$ & 0.22 & $<0.01$ \\
\hline Stomach & 7.09 & 0.19 & $8 \cdot 72$ & 0.20 & $<0.001$ \\
\hline $\begin{array}{l}\text { Gastrocnemius and } \\
\text { soleus muscles }\end{array}$ & 6.03 & 0.19 & $6 \cdot 21$ & 0.18 & $>0.5$ \\
\hline Femur & 3.67 & 0.10 & 4.08 & 0.09 & $<0.01$ \\
\hline Tibia & $2 \cdot 78$ & 0.10 & $2 \cdot 93$ & 0.09 & $>0.2$ \\
\hline Submaxillary glands & 2.88 & 0.09 & $2 \cdot 87$ & 0.08 & $>0.9$ \\
\hline Spleen & $2 \cdot 48$ & 0.20 & $2 \cdot 08$ & 0.07 & $>0.05$ \\
\hline Skin $\left(\mathrm{g} / \mathrm{r} 075 \mathrm{~mm}^{2}\right)$ & 0.870 & 0.025 & 0.815 & 0.021 & $>0.1$ \\
\hline Residual carcass & 819 & 3 & 807 & 4 & $<0.05$ \\
\hline Total body-wt (g) & 105.4 & $3 \cdot 0$ & IOI.5 & $4 \cdot 0$ & $>0.4$ \\
\hline
\end{tabular}

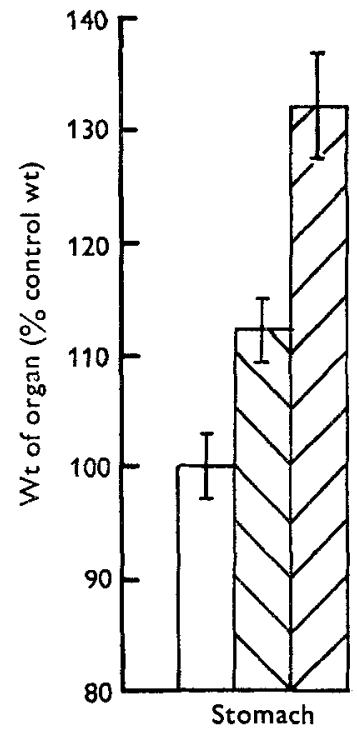

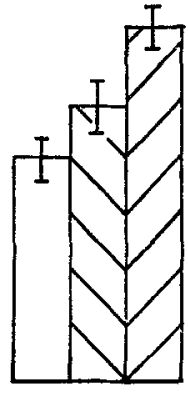

Femur

Organ

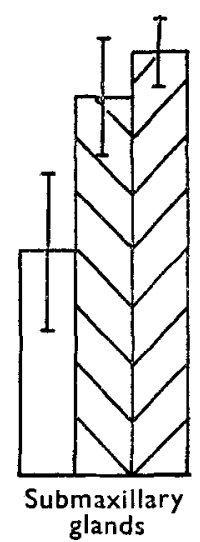

glands

Fig. 2. Expt 2. Relative weights of stomach, femur and submaxillary glands from weanling male rats consuming equal daily amounts of food for $42 \mathrm{~d}$; continuously fed, control rats $(\square)$, rats eating three meals/d $(\nabla)$ and meal-eating rats $(\nabla)$. Mean values for twelve rats/group, with standard errors represented by vertical bars. For details of diets and feeding regimens, see pp. 97-8. 


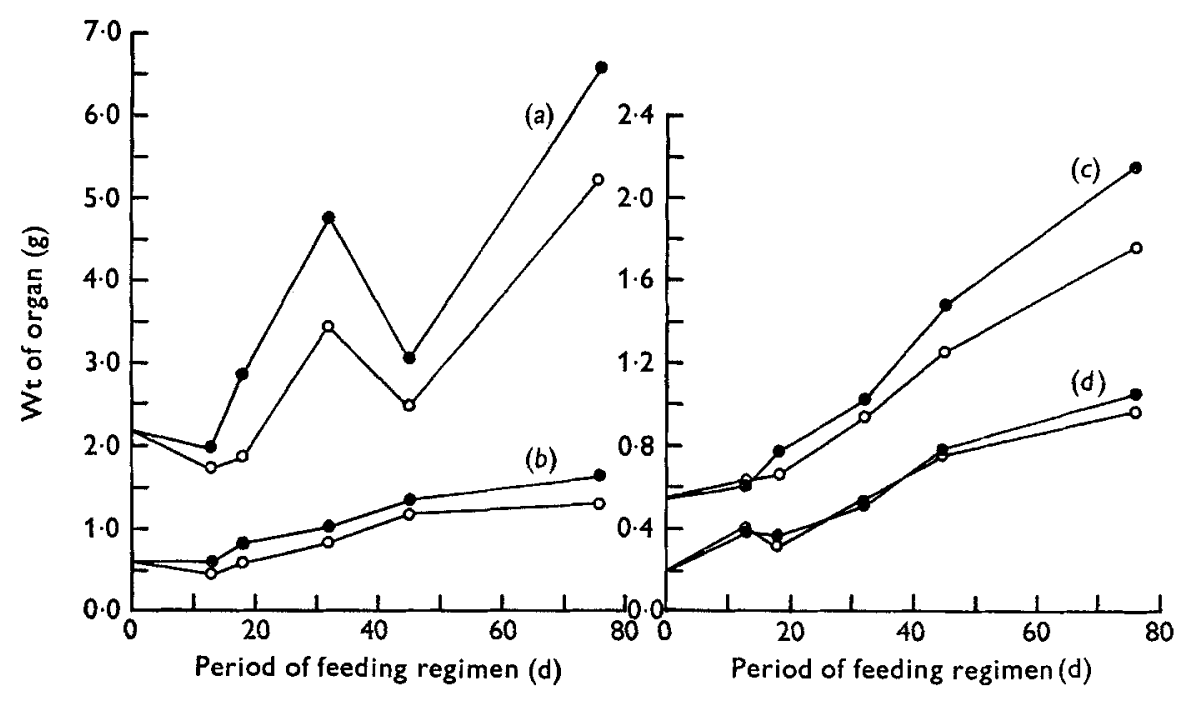

Fig. 3. Expt 3. Weights of $(a)$ small intestine, $(b)$ stomach, $(c)$ kidney, $(d)$ femur from mealeating $(O)$ and continuously fed $(O)$ weanling male rats consuming equal daily amounts of food for various periods up to $75 \mathrm{~d}$. Each point represents the mean value for six rats. For details of diets and feeding regimens, see pp. 97-8.

compared with that for the control rats $(P<0.05)$. The weights of the heart and thymus were also compared in this experiment but no significant differences were found. In rats receiving the same daily amount of food in three separate meals the weight of the organ was often intermediate between that in meal-eating and control animals. This was particularly evident in the stomach, femur and submaxillary glands (Fig. 2), suggesting that the extent of hypertrophy may be inversely related to the frequency of feeding, but the reduction in the weight of the spleen did not suggest this relationship.

The results of Expt 3, in which both groups of rats grew to a body-weight of $300 \mathrm{~g}$, indicated that the effect of meal-eating on the growth of individual organs persisted into the adult state. The weights of the stomach and small intestine were consistently greater in meal-eating than in control rats from the $13^{\text {th }}$ day onwards, and by the I8th day differences in kidney and femur were apparent (Fig. 3). No statistically significant differences between groups in the weights of liver or spleen were found in this experiment, but the trends were similar to those found previously.

\section{Chemical composition of organs in meal-eating and control rats}

The gross composition of the liver, kidneys, spleen and femur was studied in the rats from Expt $\mathrm{r}$. No difference was found between the concentrations of water, lipid or $\mathrm{N}$ in the soft tissues from the two groups of animals (Table 2), but the total amount of dry matter (DM) differed significantly in all four organs and confirmed the results for fresh weight given in Table I. The proportions of water and ash in the femur were also unaffected by the feeding regimen, but the concentration of ash was slightly decreased in the liver and increased in the kidney of meal-eating rats compared with 
Table 2. Expt I. Composition of organs from meal-eating and continuously fed (control) weanling male rats after $24 d$ on the respective feeding regimens $\dagger$

(Mean values with their standard errors for twelve rats/group for water content and for six rats/group for other constituents)

\begin{tabular}{|c|c|c|c|c|c|c|c|c|c|}
\hline \multirow[b]{2}{*}{$\begin{array}{l}\text { Organ } \\
\text { Liver }\end{array}$} & \multirow[b]{2}{*}{$\begin{array}{l}\text { Feeding regimen } \\
\text { Control } \\
\text { Meal-eating }\end{array}$} & \multicolumn{2}{|c|}{$\begin{array}{c}\text { Water } \\
(\mathrm{mg} / \mathrm{g} \text { fresh wt) }\end{array}$} & \multicolumn{2}{|c|}{$\begin{array}{c}\text { Lipid } \\
(\mathrm{mg} / \mathrm{g} \text { dry } w t)\end{array}$} & \multicolumn{2}{|c|}{$\begin{array}{c}\text { Nitrogen } \\
\text { (mg/g dry wt) }\end{array}$} & \multicolumn{2}{|c|}{$\begin{array}{c}\text { Ash } \\
\text { (mg/g dry wt) }\end{array}$} \\
\hline & & $\begin{array}{l}\text { Mean } \\
756 \\
751\end{array}$ & $\begin{array}{r}\mathrm{SE} \\
2 \\
3\end{array}$ & $\begin{array}{c}\text { Mean } \\
8_{5} \\
83\end{array}$ & $\begin{array}{r}\text { SE } \\
8 \\
6\end{array}$ & $\begin{array}{l}\text { Mean } \\
126 \cdot 7 \\
128 \cdot 6\end{array}$ & $\begin{array}{l}S E \\
I \cdot 2 \\
I \cdot 7\end{array}$ & $\begin{array}{r}\text { Mean } \\
5 \times \cdot 6 \\
48 \cdot 7\end{array}$ & $\begin{array}{l}S E \\
0 \cdot 2 \\
I \cdot 0^{*}\end{array}$ \\
\hline Kidneys & $\begin{array}{l}\text { Control } \\
\text { Meal-eating }\end{array}$ & $\begin{array}{l}75^{8} \\
752\end{array}$ & $\begin{array}{l}2 \\
2\end{array}$ & $\begin{array}{l}119 \\
114\end{array}$ & $\begin{array}{l}4 \\
7\end{array}$ & $\begin{array}{l}129 \cdot 6 \\
129 \cdot 6\end{array}$ & $\begin{array}{l}I \cdot 5 \\
I \cdot 3\end{array}$ & $\begin{array}{l}52 \cdot 6 \\
54 \cdot 9\end{array}$ & $\begin{array}{l}0.8 \\
0.4 *\end{array}$ \\
\hline Spleen & $\begin{array}{l}\text { Control } \\
\text { Meal-eating }\end{array}$ & $\begin{array}{l}715 \\
716\end{array}$ & $\begin{array}{l}\text { I4 } \\
\text { I0 }\end{array}$ & $\begin{array}{l}193 \\
216\end{array}$ & $\begin{array}{l}26 \\
26\end{array}$ & $\begin{array}{l}142 \cdot 9 \\
146 \cdot 2\end{array}$ & $\begin{array}{l}3 \cdot 0 \\
\text { I' } 5\end{array}$ & $\begin{array}{l}64 \cdot 6 \\
65 \cdot 7\end{array}$ & $\begin{array}{l}3 \cdot 2 \\
2 \cdot 6\end{array}$ \\
\hline Femur & $\begin{array}{l}\text { Control } \\
\text { Meal-eating }\end{array}$ & $\begin{array}{l}47 r \\
465\end{array}$ & $\begin{array}{l}6 \\
5\end{array}$ & - & - & - & - & $\begin{array}{l}553 \\
556\end{array}$ & $\begin{array}{l}9 \\
6\end{array}$ \\
\hline
\end{tabular}

* Mean value for meal-eating rats was significantly different from that for control rats: $P<0.05$.

$\dagger$ For details, see pp. 97-8.

Table 3. Expt I. Dry matter (DM):DNA ratio for organs from meal-eating and continuously fed (control) weanling male rats after $24 d$ on the respective feeding regimens $\dagger$

(Mean values with their standard errors; no. of determinations in parentheses)

\begin{tabular}{|c|c|c|c|c|}
\hline \multirow{3}{*}{$\begin{array}{l}\text { Feeding regimen } \\
\text { Organ }\end{array}$} & \multicolumn{4}{|c|}{ DM:DNA $(\mathrm{mg} / \mu \mathrm{g})$} \\
\hline & \multicolumn{2}{|c|}{ Control } & \multicolumn{2}{|c|}{ Meal-eating } \\
\hline & Mean & SE & Mean & $\mathrm{SE}$ \\
\hline Liver (I2) & 90.5 & 30 & $89 \cdot 0$ & 3.0 \\
\hline Kidney (5) & $45 \cdot I$ & 0.7 & $5 \times \cdot 3$ & $0.3^{*}$ \\
\hline Spleen (5) & $15 \cdot 6$ & 0.3 & $15 \cdot 8$ & 0.3 \\
\hline
\end{tabular}

* Mean value for meal-eating rats was significantly different from that for control rats: $P<0.001$. $\dagger$ For details, see pp. $97^{-8}$.

control animals. However, as these differences were small and of doubtful biological significance, they were not studied further.

The amount of DNA in all diploid cells of an organism is very consistent (Thompson, Neagy, Hutchinson \& Davidson, 1953), and the DM:DNA ratio was therefore estimated as an index of cell size for organs for which there was a difference in weight between the two groups of rats. No difference was found in the liver or spleen (Table 3), implying that the increased weight of the liver and decreased weight of the spleen in meal-eating rats were associated with changes in the number of cells present. In the kidney of meal-eating rats, however, the DM:DNA ratio was significantly increased by $11.4 \%$, which was in good agreement with the $11.0 \%$ increase in mean fresh weight of the organ in the same animals, and indicated that the hypertrophy of the kidney was due principally to an increase in cell size. 


\section{DISCUSSION}

The results of this study indicate that the frequency of food intake does affect the growth of several organs in the rat. Consistent increases in the weights of the stomach, small intestine, femur, kidneys and liver were found in meal-eating animals in all three experiments, and the results of Expt 3 indicate that these are permanent effects which continue into the adult state. Enlargement of the submaxillary glands was found only in Expt 2, which could be because the rather dry unpalatable nature of the powdered cubes required a greater flow of saliva than the synthetic diet. It was noticeable that in this experiment the animals grew more slowly than those given synthetic diets in Expts I and 3, although the food consumption was higher.

The similarity of the increases in total body-weight always found in meal-eating rats and in continuously fed, control rats which consumed the same daily amount of food but at frequent intervals, indicates that the greater weight of these organs is due to selective growth rather than to differences in the efficiency with which ingested food was utilized. In addition to the reduction in size of the spleen, compensatory changes must have occurred elsewhere in the body, and the smaller weight of the residual carcass in meal-eating rats confirms this (Table I). Skeletal muscle, skin, or perhaps blood, seem to be the only tissues likely to accommodate changes of the necessary magnitude, but the gastrocnemius and soleus muscles gave no indication of any reduction in size.

No differences were found between the gross chemical composition of the liver, kidneys, femur or spleen in meal-eating and control animals (Table 2), which is consistent with the normal proportions of DM and $\mathrm{N}$ found by Fábry \& Kujalová ( 1960 ) in the enlarged small intestine from intermittently fed rats. Although increased rates of lipogenesis occur in the liver and adipose tissue of meal-eating rats (Leveille, 1967) and meal-eating has been reported to increase the proportion of fat in the whole carcass (Cohn, Joseph, Bell \& Allweiss, 1965), these findings indicate that the differences in organ size found in the present study were not the result of changes in the metabolism of any single type of major cell constituent, but appeared to be due to changes in the general growth rate of the individual organs.

Considerable variations in mean cell size between liver, kidney and spleen were indicated by the DM:DNA ratio (Table 3 ) and the mechanism of the change in organ size also varied. The hypertrophy of the kidney from meal-eaters was due principally to an increase in cell size, but the increased weight of the liver and reduced weight of the spleen from the same animals appeared to be due to a change in the number of cells present. This difference in the mechanism of the response may be explicable by the varying age of maturation in different organs. The number of nuclei in a rat kidney stabilizes at about $3 \mathrm{I} \mathrm{d}$ after birth and further growth is then due entirely to cell enlargement, whereas the number of nuclei in liver and spleen increases progressively until at least 95-99 d of age (Enesco \& Leblond, 1962; Winick \& Noble, 1965). The animals in which cell size was determined in the present study were $45 \mathrm{~d}$ of age, therefore the increase in number of kidney cells would have ended about 
half-way through the experimental period, but development would still be continuing in the liver and spleen.

These effects of a meal-eating pattern of feeding imply that it may be necessary to control the frequency of food intake, in addition to the total amount of food consumed, in nutritional studies where changes in dietary composition are likely to influence the animals' appetite. The enlargement of the stomach and small intestine in mealeating animals is well established (Fábry, 1969) and can be readily understood as an adaptation to facilitate efficient utilization of food that is only ingested intermittently. The changes found in liver, and particularly those in kidney, femur and spleen are, however, much more difficult to explain in this way, and suggest that the frequency of food intake has a much more widespread influence on metabolism than is generally recognized.

The authors thank the Science Research Council for the award of a studentship to R.C.P.

\section{REFERENCES}

Alfaro, B. \& Heaton, F. W. (1973). Br. F. Nutr. 29, 73.

Cohn, C., Joseph, D., Bell, L. \& Allweiss, M. D. (1965). Ann. N.Y. Acad. Sci. 131, 507.

Enesco, M. \& Leblond, C. P. (1962). F. Embryol. exp. Morph. то, 530.

Fábry, P. (1967). In Handbook of Physiology. Section 6: Alimentary Canal, vol. I, p. 3 I [C. F. Code, editor]. Washington, DC: American Physiological Society.

Fábry, P. (1969). Feeding Pattern and Nutritional Adaptations. London: Butterworth \& Co. Ltd.

Fábry, P. \& Kujalová, V. (1960). Acta anat. 43, 264.

Heaton, F. W. \& Loveless, B. W. (1973). Proc. Nutr. Soc. 32, I8A.

Hofert, J. F. \& White, A. (1968). Endocrinology 82, 767.

Hubbard, R. W., Matthew, W. T. \& Dubowik, D. A. (1970). Analyt. Biochem. 38, 190.

Le Magnen, J. (1967). In Handbook of Physiology. Section 6: Alimentary Canal, vol. I, p. I I [C. F Code, editor]. Washington, DC: American Physiological Society.

Leveille, G. A. (1967). Proc. Soc. exp. Biol. Med. 125, 85.

Leveille, G. A. (1972). F. Nutr. 102, 549.

Leveille, G. A. \& Hanson, R. W. (1966). F. Lipid Res. 7, 46.

Loveless, B. W., Williams, P. \& Heaton, F. W. (1972). Br. F. Nutr. 28, 26 I.

Thompson, R. Y., Neagy, F. C., Hutchinson, W. C. \& Davidson, J. N. (1953). Biochem. F. 53, 460.

Winick, M. \& Noble, A. (1965). Devl Biol. 12, 45 I. 